\title{
Ergonomic work analysis as a tool of prevention for the occupational safety and health management system
}

\author{
Verônica de Miranda Prottes ${ }^{\mathrm{a}}{ }^{*}$, Nádia Cristina Oliveira $^{\mathrm{a}}$ and Alessandra Barbosa de Oliveira Andrade \\ a Industrial Engineer and Safety Engineer from the Pitágoras College. \\ ${ }^{\mathrm{b}}$ Ergonomics Consultant of the Bioergo Ergonomics Consulting Company, Avenida Contorno 7290, Lourdes, \\ Belo Horizonte, MG, Brazil, CEP 30110-048.Email: bioergo@bioergo.com.br
}

\begin{abstract}
This paper introduces the Ergonomic Work Analysis as a relevant instrument to identify the risks in occupational environments through the investigation of factors that influence the relationship between the worker and the productive process. It draws a parallel between the several aspects of risk identification in traditional tools of Health and Safety Management and the factors embraced by the Ergonomic Work Analysis, showing that the ergonomic methodology is able to go deeper in the scenarios of possible incident causes. This deepening enables the establishment of a relationship between the work context and the upcoming damage to the physical integrity of the worker. It acts as a complementary instrument in the traditional approach to the risk management. In order to explain the application of this methodology in a preventive way, it is presented a case study of a coal mill inspector in a siderurgic company.
\end{abstract}

Keywords: Ergonomic Work Analysis. Risk Management. Occupational Health and Safety System.

"Corresponding author. Address: Rua Jacaraípe, 792/301, Giovanini, Coronel Fabriciano - MG, Brazil. CEP 35170095. Tel.: +55 31 92358756. E-mail: veronicaprottes@hotmail.com. 


\section{Introduction}

The present article aims to explain the importance of the Ergonomic Work Analysis (E.W.A.) as an instrument of risk identification in working environments by using the systematic study of the relationship between the man and his work. The strong point of this approach is, as stated by Lima (2000) $[8]^{2}$ "the detailed analysis of the work situations that can identify and eliminate the immediate causes of accidents, illnesses and work overload that create harmful situations."

The analysis of the human-work interface is mediated by new legal requirements that seek to reduce public expenses. It is justified by the preliminary cost of social security benefits in Brazil due to accidents and illnesses plus the payment of special retirement under working conditions equal to $\mathrm{R} \$ 11.60$ billion in 2008 [6].

Therefore one could question the effectiveness of methods and tools of risk management to reduce the likelihood of accidents. In this context, the question that arises is: how E.W.A. can help the Health and Safety Management System? Within the NR-17 $7^{3}$ [9], drafted by Ordinance No. 3751 of 11.26 .1990 , item 17.1.2 recommended $^{4}$ :

"To evaluate the adaptation of working conditions to the psychophysiological characteristics of workers, the employer should perform the Ergonomic Work Analysis. And it should at least address the working conditions as provided in this Regulatory Standard."

This method of analysis, based on French ergonomics, does not eliminate the need of using tools of risk analysis already known in the Health and Safety Management, but provides means to extend the limits of in-depth understanding of the problems in the work process and to prevent work accidents and occupational diseases. This understanding will assist the process of Risk Management at work and improve the Health and Safety System.

In order to illustrate the importance of this tool, not only to identify ergonomic hazards but also occupational accidents and illnesses, this paper proposes a case study carried out in an siderurgic company, which elucidates aspects of risks that come

\footnotetext{
${ }^{2}$ Quotation translated by the authors of this paper.

${ }^{3}$ NR-17 is part of a set of Regulatory Standards in Occupational Safety and Health of the Ministry of Employment in Brazil.

${ }^{4}$ Quotation translated by the authors of this paper.
}

from a poor relationship between man and his work, encompassing aspects of the occupational environment. From this poor interaction come the risks of accidents and occupational diseases.

\section{The approach to traditional methods of risk management at work}

According to Calixto (2006) [4], the risk management appears as a process that involves the use of many resources such as human, material, financial and technological, that are focused on the prevention of accidents that cause health damages to workers and environmental impacts. For the action to be effective it is necessary the identification of the risks, the planning of preventive, blocking, and monitoring actions, and the critical analysis for continuous improvement and learning.

However, it is noteworthy that this study draws on the phases of identification and risk analysis only. Since the focus of the E.W.A. is on the identification and that serves as a pillar for a more robust risk analysis.

\subsection{Traditional Tools of Risk Identification}

The first stage of the risk management process is characterized by the identification of potential sources of damage or hazards in the workplace. After that, the information gathered are addressed to the tools of risk analysis which are Preliminary Hazard Analysis (PHA), Failure Mode Effects Analysis (FMEA), Critical Incident Technique, Fault Tree Analysis (FTA), among others.

Currently, taking account of the most used tools by the HSMS (Health and Safety Management System) to the identification of risks, the ones that stand out are: the checklists, the safety inspections and the flowcharts. These techniques are based on observations of the environment using items to be checked or evaluated by a predetermined script, generally supported by the relevant legislation, and have the need to compare situations with pre-established standards.

The safety inspections are based on the search of common risks that are theoretically already known. If the person responsible for the inspection notices any irregularity he reports the nonconformities that were detected, using a pre-established set of rules (ROSA, 2009) [17]. 
Flowcharts are graphical representations of processes or activities and they feature the operations and the responsible people involved. (Oliveira, 2004) [15].

The checklist, because of its easy application, is an instrument widely used by technical and safety managers of the occupational field. The technique consists of a list of verification that serves as a guide to the survey-taker in order to obtain important data for the risk analysis. Nevertheless, because it consists of a list, the technique can leave gaps when conducting the analysis of a job position or a process, because it only allows the observer to know what is explicit, leaving aside implicit issues in the work context.

\subsection{The Approach to E.W.A.}

According to Wisner, quoted in the Application Manual NR-17 (2002) [9] ${ }^{5}$, "Ergonomics is the scientific body of knowledge related to man and needed to develop tools, machines and devices that can be used with maximum comfort, safety and efficiency".

The E.W.A. (Guerin et al. 1997; WISNER, 1994) $[5,20]$ is a tool of data collection used in ergonomics that proposes the observation of real-life work contexts. It assumes that the person who uses the technique must know the workplace through the observation of daily routine activities. That occurs by the use of interviews, direct observation, selfconfrontation, video and photo records and chronological analysis of the activities.

During the observation period, it is noted the job description, the actual routine operation, the condition of the process control equipments, the furniture and the aspects related to the organization of the work like the composition of teams and relay schemes and how these variables interfere in the operational modes. Also in data collection, information should be confronted with inputs from managers, supervisors and subordinates.

When observing the real-work context, it is possible to identify the variables used by the worker to understand the issues. In order to solve such problems, the worker creates operational strategies to break the gaps that may exist between what is prescribed by the organization and what is real in his routine (Abrahão, 2000) [1].

\footnotetext{
${ }^{5}$ Quotation translated by the authors of this paper.
}

The efficacy of the observation relies precisely in providing the researcher and $\mathrm{OSH}$ managers a systematic overview of the worker activities, including the interactions between the subject of analysis and the various components of the work system. For this facet, the E.W.A. differs from the traditional view of work safety that is still in use, which states that the worker behavior is the strict condition that generates the risk occurrences. As stated by Oliveira (2003) $[13]^{6}$ :

"The approach to workplace safety that states that the worker is wrong when executing his job because he is careless, undisciplined, reckless or simply imprudent (principles on which the 'Insecure Act' is based on) is as dangerous to the work safety management as it is the belief that the worker at his own risk never makes mistakes."

Therefore the E.W.A. allows possible risk sources and potential accidents to be shown from the relationship man $x$ job. In light of that the vision focused on the error ceases to be a central part of those who deal with the prevention of accidents and become the cause of that error that can be apparent or hidden, remote or immediate. And that is an essential factor for the reduction or elimination of the causes of accidents.

\subsubsection{Restrictions on the use}

The E.W.A. can identify risk situations in the workplace but its application must be performed by competent personnel with multidisciplinary knowledge in ergonomics and safety at work. The personnel would be responsible for covering the various aspects of the task, to ensure its effective implementation and not just be a mere tool that carries a superficial understanding of work issues. It is suggested that E.W.A. is applied in conjunction with other tools and is included in a continuous improvement plan of the company, due to the changeability of the work environment.

\subsection{The interface between the Ergonomic Method and the Traditional Methods in OSH-Occupational Safety and Health}

The E.W.A. provides a different view of the work analysis that the usual tools of OSH do not have, because E.W.A. considers the individual as an

\footnotetext{
${ }^{6}$ Idem.
} 
integral part of the work process and recognizes the relevance of the information given by him. So the work environment is considered as a whole without ignoring any of the elements of the work process, especially in light of the knowledge that the workers have themselves about their work. According to Abrahão and Pinho (1999) [2] :

"The vision of workers is an important source of information to guide the initial hypotheses, data collection and data accuracy. This does not mean an inversion of the relationship between research and professional practice but the fact that the construction of knowledge is made from the subject and also the practice / research. In this process the value of coherence of the speech with the identified events must be kept through the established relations via the systematic observations of the activity in real work situations."

As for the traditional techniques of risk identification, Lima (2000) $[8]^{8}$ considers that

"First, who uses them takes the risk of seeing only what the list lets one see. Thus everything that can be different from what is already known about the problem is left out."

Nascimento et al (2006) [11] $]^{9}$ also deals with the range of tools for identifying risks:

"Therefore the framework is to cover the issue of occupational risk from a logic that values the applicability of techniques for the identification and management of potential harmful elements in the workplace, by tracking those elements without taking into account the human and environmental variability nor the knowledge of employees as contribution in this identification and management."

From the statement above it is observed that the weakness of the identification tools in the risk management is the act of observing the environment as a static place, not dynamic, which implies the nonobservation of important risk factors that are implicit and can be the background for the occurrence of accidents.

Thus, if the risk management is focused on the safety of the worker, and he is exposed to the risks of incidents, one cannot evaluate the risk without

\footnotetext{
${ }^{7}$ Quotation translated by the authors of this paper.

${ }^{8}$ Idem.

${ }^{9}$ Idem
}

taking into account the worker's participation as an integral element to the work system.

It is precisely this gap in the traditional methods of risk management that the E.W.A. can fill, as a basis for identifying factors that can potentially cause injury or cause the emergence of occupational diseases. This happens by the recognition of elements such as: intensity and duration of work, physical and mental workload, division of labor and tasks, interpersonal relationships and factors related to biomechanics and others. Those aspects can affect the individual in complying with their work activities which generates favorable situations to the emergence of incidents.

Consequently, this ergonomic analysis will act as a preventive tool, as it complements the tools of risk management with data about the work system in regard to the identification of hazards and risks, assisting in the safety management of workplaces. But in this case, the environments will not be analyzed statically or after the occurrence of damage, but in conjunction with the very ergonomic monitoring in a preventive way.

\section{Methodology}

In the original approach of this article, it is intended to adopt the explanatory research, cited by Brasileiro and Santos (2007: 68) [3] ${ }^{10}$ as a research that "aims to explain the occurrence of a phenomenon and justify the factors that interfere in its outcome." Moreover, this study has an exploratory purpose, since it requires a deepening in the subject because of the scarcity of bibliography in the topic.

As a consequence of the argument above, the deductive logic was chosen, because it uses the conventional risk management tools and the ergonomic analysis methodology to test its applicability in a specific case.

It also has a qualitative approach, as it seeks to analyze the effect of the E.W.A. application in a work situation through the analysis of its validity for risk identification.

In relation to the investigative means, we chose the field research to be reported in a case study. It was performed in situ in a siderurgic company to collect relevant data of the work under the methodo-

\footnotetext{
${ }^{10}$ Idem.
} 
logical principles of Ergonomic Work Analysis and compare the obtained observations with the bibliography used here as a reference. The work environment was studied due to the easy comparison between the different facets of the worker interaction with the system and other workplaces with semiautomation features, such as the case of this article.

\section{Discussion of results}

\subsection{The System of Coal Drying and Grinding}

The System of Coal Drying and Grinding is an engineering package that was purchased to use coal as fuel in blast furnaces. For this purpose, the coal must be dried and ground to a particle size needed to get the burning almost instantly. This process is called the injection of coal fines.

In the observed company, the package includes three mill plants to support the expected demand. The coal comes from a storage yard and it is sent to conveyor belts with the use of machines that gathers the material. So when the coal gets to the silos it is sent to the mills for grinding. The process is controlled online via PLC (Programmable Logic Controller) in supervisory panels in a control room. The inspector makes the physical control of the process to ensure that the information generated by the system match the reality. In addition, he is responsible for performing manual tasks to control the plants and ensure smooth operation of the process.

\subsection{The Case of the Plant Inspector of the Coal Dry- ing and Grinding System}

It was observed the routine of this inspector in an everyday situation of work. In order to facilitate the interpretation of the data given by the worker, it was previously consulted the description of such position. By analyzing his real activities it was possible to identify some factors that contribute to the relative unpredictability of the routine of this operator. The main factor is due to the clogging of various gutters and pipes in the three mill plants of Coal Drying and Grinding. This task is not formally recognized by the description of his position.

The task of correcting the problem is linked to manual intervention by the inspector in the sites of blockage; he uses various tools to unclog the gutters and the mill throat. The activity must be done with a shovel that the operator uses to scrape the sides of the gutter and push the wet coal into the mill. Using the same tool, he clears the sluice and the throat which are located below the gutter. He also uses the nitrogen rod (under pressure), to loosen the coal that is stuck on the walls of the gutter and throat. It is shown the layout of the Coal Drying and Grinding plant to elucidate this activity.

In this scenario, the operational modes are developed due to the physical and organizational structure offered by the company to the worker. According to Oliveira \& Prottes (2008) [14], the operational mode is "the method of carrying out the real activity by the use of the company prescription and what it actually has as a resource to its job."

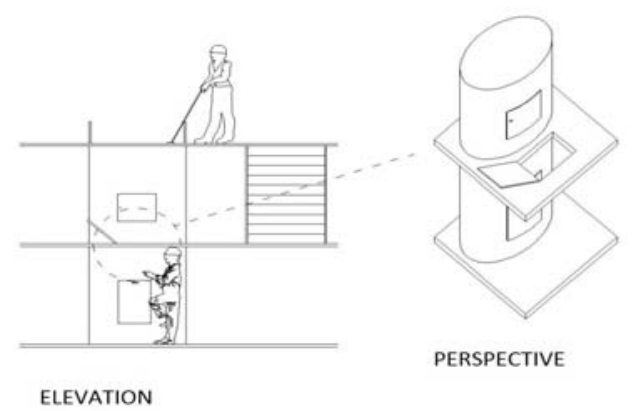

Figure 1 - Simplified Perspective and Elevation of the Coal Drying and Grinding System

4.2.1 The elucidation of the risk aspects and its relation with E.W.A.

In the described activity, no dust mask is used for the task in which there is direct contact with coal dust. When questioned about it, the operator said that besides the discomfort generated by the use of PPE (Personal Protective Equipment), there was not any available in stock, since it was "expensive" (according to collected information). In addition, the worker also evinced that he did not trust in the protection of the equipment. Despite that assertion, the fact is that the equipment was not being used and it was observed that there was no supervision on the use.

The assertion made by the worker that there is discomfort in the use of Personal Protective Equipment and his failure to use it due to "lack of stock" is an attitude of carelessness or negligence in the traditional view of safety. However, this "negligence" may become an apparent symptom of a dee- 
per dysfunction in the OSH system. The operator does not use the equipment for "not having in stock and being very expensive," which refers to an organizational posture that deprives workers of the prevention of accidents and occupational diseases.

This approach may generate the same effect on employees who start to underestimate the risks, bring them into their routine and treat them as the company does, and that reduces the possibilities for improving the industrial environment ( OLIVEIRA, 2007) [12].

Another important risk aspect was the performance of the activity even in the absence of the support platform for the feet that is essential for a worker who was at a height of more than three meters. The security platform to get to the throat had been removed for maintenance reasons so the worker was left without footrest to perform his activity.

In order to accomplish the task, he stepped on a tank that is located in front of the mill and has smooth domed structure that allows a downside risk for slippage. When asked about why the activity was being done in an unsafe manner, the worker said: "I could refuse to do the service, but production can not stop and I could be warned". This may be an indication of how the operator interprets the $\mathrm{OSH}$ management system of the company and that leads us to think that production has priority over safety, even though it is not clearly stated on the workers routine, training or in the SIPAT's ${ }^{11}$.

The same analysis was performed by Oliveira (2007) $[12]^{12}$ who did a research on the concept of safety and accidents in a metallurgic company in Sao Paulo. The interviews and self confrontations made with 20 different workers resulted in the following conclusion:

"The relation between workers and their recognition of unsafe working conditions is a serious dilemma experienced daily by them. On the one hand many interviewees said about the requirement that all workers have to check work conditions and not accept unsafe conditions. On the other hand, they show a fear of refusing to work and being targeted for retaliation."

\footnotetext{
${ }^{11}$ Internal week for The Prevention of Occupational Accidents preconized by the Ministry of Employment in Brazil in the NR-5 (Regulatory Standard 5)

${ }^{12}$ Quotation translated by the authors of this paper.
}

This example shows how the worker's behavior is affected by his perception of risk and how he sees the corporate responsibility in relation to Health and Safety at work. This behavior is normally reinforced by the Health and Safety training that considers the accident as human's fault and at the same time states that the very unsafe condition is created by man.

Another important aspect is that the training is based on the risk conditions of workplaces and activities prescribed by the company. The lack of knowledge of the real activity leads to the ultimate lack of knowledge of the risk issues. Thus, this approach transfers all the company liability to the employee and creates a system of blame (VIEIRA et.al, 2007) [19] that turn the man into the central element of any accident.

$$
\begin{aligned}
& \text { Contradicting this assumption Oliveira } \\
& {[13]^{13} \text { states: }}
\end{aligned}
$$

"The worker behavior, as expressed in the action of the accident, although it has been the leading cause is of secondary importance or even irrelevant at times. The determinants of behavior or what motivated the actions are what should be considered by all means and carefully studied, like: what was wrong with the environment, the labor relations, and even events in the life of the employee that directly or indirectly interfered in his relation with his work and defined his right or wrong attitude."

In the presented study, the E.W.A. enabled the identification of the aspects of potential risk to the worker in its operative mode. This methodological proposal, that is different from the traditional Safety Management System, involves the deeper analysis of issues that are normally interrelated but easily taken for granted, like: the determinants of a reasonable secure behavior of workers such as physical, organizational and cultural aspects of the company that shape the way the "collaborators" see the risks and run their activities. The ergonomic analysis emphasizes the determinants of human behavior and not the behavior itself, in order to distinguish the elements that make the workplace a local source of illnesses and accidents.

\footnotetext{
${ }^{13}$ Idem.
} 


\section{Concluding Remarks}

In the risk management system of the companies, the tools of risk identification must be useful for the analysis of work contexts in its various aspects. The better the capacity of the tools to identify situations of arduous work the better the analysis in risk management, and that makes the process more robust and effective.

In this study, it is noticeable the scope and applicability of E.W.A., which goes beyond the common notion that behavior is guided by carelessness and sees organizational factors, resources provided by the company and social aspects that are interrelated with the "actor" impacting on his work and his safety.

Over the case study we observed that several factors interfered in the process of decision making by

\section{References}

[1] Abrahão, Júlia Issy. Reestruturação Produtiva e Variabilidade do Trabalho: Uma abordagem da Ergonomia. Psicologia: Teoria e Pesquisa. Jan-Apr 2000, volume 16, n.1, pp. 49-54.

[2] Abrahão, Júlia Issy. Pinho, Diana Lúcia Moura. Teoria e prática ergonômica: seus limites e possibilidades. In, M.G.T. Paz, e A. Tamayo, (Org.) Escola, saúde e trabalho: estudos psicológicos (pp. 229-240). Brasília: The University of Brasília Publishing House, 1999.

[3] Brasileiro, Ada Magaly Matias, Santos, Viviane Pereira dos. Estilo e Método. Produção de trabalhos Acadêmicos. Damasceno, Ipatinga, 2007.

[4] Calixto, Eduardo. Uma metodologia para gerenciamento de risco em empreendimentos: Um estudo de caso na indústria de petróleo. Paper published in XXVI ENEGEP - Fortaleza, CE, October 09th to 11th, 2006.

[5] Guérin, F.; Laville, A., Daniellou, F.; Durrafourg, J. and Kerguellen, A. (1997). Compreendre le travail pour le transformer. La pratique en Ergonomie. Paris: Collection Outils et Méthodes, Editions ANACT, 2ème édtion.

[6] http://www.previdenciasocial.gov.br/. Visited on October 13 th, 2009.

[7] Iida, Itiro. Ergonomia: Projeto e Produção. Edgard Blücher. São Paulo, 2005.

[8] Lima, Francisco de Paula Antunes. A ergonomia como instrumento de segurança e melhoria das condições de trabalho. Paper published in the Annals of The First Brazilian Symposium ERGOFLOR, Belo Horizonte/Viçosa: The Federal University of Viçosa/Fundacentro, 2000, pp. 1-11.

[9] Manual de aplicação da Norma Regulamentadora n. 17. 2. Brasília: MTE, SIT, 2002

[10]Miguel, Paulo Antonio Cauchick. Segismundo, André. O papel do FMEA no processo de tomada de decisão em desenvolvimento de novos produtos: Estudo em uma empresa automotiva. Paper published in the Magazine "Pro- the individual, increasing the likelihood of accident risks. Thus, it was observed that the Ergonomic Analysis of Labor was able to identify various situations that could be not noticed in a normal safety inspection if the environment was seen in a static way. The conventional tools together with the analysis of E.W.A. will allow the establishment of prioritizing the risks and therefore the management of continuous improvement of the working environment. However, their indiscriminate use by untrained people can generate superficial analysis, which goes against the proposal of this methodological tool.

The study also demonstrates that despite the applicability of E.W.A., it can not be used alone but as a complement to conventional tools used in $\mathrm{OSH}$, as it allows a visualization of risk, anticipation of events and is helpful in the preventive approach.

duto\&Produção", vol. 9, n. 2, p. 106-119, feb. 2008. Avaliable on http://www.seer.ufrgs.br/i. Visited on 11/26/2009.

[11]Nascimento, Elvia Lane Araújo do. Cunha, Tânia Batista da. Feitosa, Josefa Sônia. Das metodologias tradicionais à psicodinâmica do trabalho: reflexões sobre a prevenção de riscos ocupacionais. Paper published in XVII ENEGEP Fortaleza, CE. October 09th to 11th, 2006.

[12] Oliveira, Fabio de. A persistência da noção de ato inseguro e a construção da culpa: os discursos sobre os acidentes de trabalho em uma indústria metalúrgica. Magazine: "Revista Brasileira de Saúde Ocupacional”, São Paulo, 32 (115): pp.19-27, 2007.

[13] Oliveira, João Candido de. Segurança e Saúde no Trabalho: uma questão mal compreendida. Magazine: "São Paulo em Perspectiva", 17 (2): 3-12, 2003. Available on www.scielo.br. Visited on $10 / 17 / 2009$.

[14] Oliveira, Nádia Cristina. Prottes, Verônica de Miranda. O Uso da Ergonomia como Ferramenta de Análise dos Fatores que Conduzem ao Erro Humano e Melhoria de Postos de Trabalho no Setor Siderúrgico. Monograph presented to the Pitágoras College. Ipatinga, 2008.

[15] Oliveira, Djalma de Pinho Rebouças de. Sistemas, organização e métodos - uma abordagem gerencial. São Paulo: Atlas, 2004.

[16]Pegatin, Thiago de Oliveira. Silva, Fábio Molina. Análise Ergonômica de um Posto de Trabalho numa fábrica de calçados. Paper published in XI SIMPEP - Bauru, SP. October 08th to 11 th, 2004.

[17]Rosa, L. C. Gerência de Riscos. In: Postgraduate in Work Safety Engineering, Santa Maria, UNIFRA, 2009. Handout.

[18] Santos, Eduardo Ferro dos. Paixão, Antônio. Análise de riscos ergonômicos através da adaptação do FMEA como ferramenta de avaliação e gerenciamento. Paper published in XXIII ENEGEP - Ouro Preto, MG. 22nd to 24th, 2003.

[19] Vieira, Carlos Eduardo Carrusca et. al. Uma abordagem da Psicologia do Trabalho, na presença do trabalho. Psicologia em Revista, Belo Horizonte, vol. 13, n. 1, p. 155-168, jun. 2007.

[20]Wisner, Alain. A inteligência no trabalho: textos selecionados de Ergonomia. São Paulo: Fundacentro, 1994. 